\title{
Efeito antimicrobiano da terapia fotodinâmica associado à nanopartículas, LASER ou LED em biofilmes de micro-organismos colonizadores iniciais
}

\section{Gabriela S. de Paula*, Luciana S. Sales, Mateus C. Oliveira, Marcelo Boriollo, Carolina Steiner-Oliveira}

\section{Resumo}

A cárie dentária e a doença periodontal são as doenças bucais biofilme-dependentes. Técnicas inovadoras de controle do biofilme usando terapia fotodinâmica antimicrobiana (TFDA) demonstraram redução microbiana em biofilmes cariogênicos maduros. No entanto, além da associação do agente fotossensível à nanopartículas, não se conhece o efeito da TFDA em biofilmes de colonização inicial. Assim, esse estudo testou o efeito da TFDA em biofilme bucal formado por micro-organismos colonizadores iniciais utilizando azul de metileno associado à nanopartículas de ciclodextrina e fonte de luz LASER ou LED. S. gordonii, S. oralis, S. mitis e S. sanguinis foram cultivados em placas de poços contendo $\mathrm{BH}$ suplementado com sacarose $1 \%$ por 24 h. Os grupos foram divididos em $(n=6)$ : C (controle), $L$ (LASER), LED (ligtht emitting diode), F(Fotossensibilizador/Nanopartícula), LF e LEDF. A redução microbiana foi avaliada pela contagem de micro-organismos viáveis do biofilme antes e após os tratamento em meios de cultura seletivos. Após análise de normalidade os resultados foram submetidos à análise de variância Kruskal-Wallis, seguido de teste de Dunn, com nível de significância de $5 \%$. Os grupos F, L e LF diferiram estatisticamente do grupo controle negativo. O grupo LF não mostrou diferença significativa comparado ao grupo controle positivo. Em conclusão, a TFDA mediada por azul de metileno conjugado à ciclodextrina irradiada por LASER foi eficaz na redução microbiana de biofilme inicial.

\section{Palavras-chave: .}

Biofilmes, Streptococcus mutans, lasers.

\section{Introdução}

A TDFA objetiva promover a redução dos microorganismos do biofilme dentário. Com a maior ingestão de açúcar, diminuição do fluxo salivar juntamente à falta de cooperação do paciente em relação ao controle mecânico do biofilme, doenças como a cárie dental e doença periodontal podem ocorrer. Assim a TFDA envolve agentes fotossensíveis que são ativados pela irradiação por uma fonte de luz de comprimento de onda específico para gerar espécies citotóxicas, incluindo oxigênio singleto e radicais livres, que promovem danos microbianos irreversíveis, resultando em morte celular.

\section{Resultados e Discussão}

Os grupos fotossensibilizador associado à nanopartícula $(F)$, laser isolado $(L)$ e fotossensibilizador/nanopartícula irradiado com luz LASER (LF) diferiram estatisticamente do grupo controle negativo, ao contrário dos grupos LED e LEDF. O grupo LF também não mostrou diferença significativa, comparado ao grupo controle positivo.

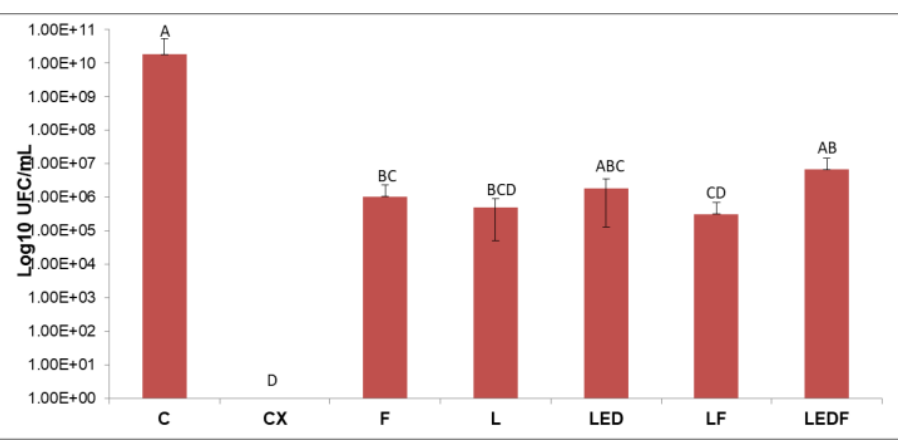

Figura 1. Viabilidade bacteriana em $\log _{10} \mathrm{UFC} / \mathrm{mL}$ em biofilme inicial formado para cada grupo.

Os grupos $F$ e $L$ também produziram efeito antibacteriano nas circunstâncias do estudo, visto que mostraram redução microbiana em relação ao grupo controle negativo. Uma explicação é que a irradiação isolada pode desempenhar um papel fisiológico e metabólico com inibição de citocromos que participam do transporte de elétrons para a fosforilação oxidativa ${ }^{1}$. O fotossensibilizador associado à nanopartícula pode ter agido por ser capaz de usar espécies moleculares menores e mais permeáveis, mais capazes de utilizar canais de água da estrutura do biofilme ${ }^{2}$. A luz LED isolada ou na TFDA não produziu efeito antibacteriano no biofilme, concordando com Quishida et al. (2015) enquanto a TFDA associada à nanopartícula irradiada com LASER foi eficaz na redução do biofilme inicia (Vasconcelos et al., 2019).

\section{Conclusões}

A TFDA mediada por azul de metileno conjugado à ciclodextrina irradiada por LASER foi eficaz na redução microbiana de biofilme inicial.

\section{Agradecimentos}

Agradecemos a colaboração da discente Victoria G. C. Geraldino da FOP-UNICAMP, à PRP UNICAMP, $\mathrm{PIBIC/CNPq}$ e Pesquisa SAE/UNICAMP.

\footnotetext{
${ }^{1}$ Tome FM, Paula Ramos L, Freire F et al. Influence of sucrose on growth and sensitivity of Candida albicans alone and in combination with Enterococcus faecalis and Streptococcus mutans to photodynamic therapy. Lasers Med Sci 2017;32:1237-1243. ${ }^{2}$ Fontana CR, Abernethy AD, Som S, Ruggiero K, Doucette S, Marcantonio RC, Boussios CI, Kent R, Goodson JM, Tanner AC, Soukos NS. The antibacterial effect of photodynamic therapy in dental plaquederived biofilms. J Periodontal Res. 2009 Dec;44(6):751-9. ${ }^{3}$ Quishida CC, Mima EG, Dovigo LN, Jorge JH, Bagnato VS, Pavarina AC. Photodynamic inactivation of a multispecies biofilm using Photodithazine ${ }^{\circledR}$ and LED light after one and three successive applications. Lasers Med Sci. 2015 Dec;30(9):2303-12. ${ }^{4}$ Vasconcelos ME, Steiner-Oliveira $C$ et al., Combined effectiveness of $\beta$-cyclodextrin nanoparticle in the photodynamic antimicrobial chemotherapy in in vitro oral biofilms. Photobiomodul Photomed Laser Surg, 2019.
} 